\title{
Політологія
}

DOI: $10.15421 / 172077$

УДК: 321.7

\section{Comparative analysis of efficiency of democracy in Ukraine according to the indices of democracy The Economist Democracy Index, Freedom In the World and Polity IV}

\section{Kateryna Fedoryshyna, Kyiv National University of Trade and Economics}

This article represents an analysis of efficiency of Ukrainian democracy within the framework of three popural indices of democracy - The Economist Democracy Index, Freedom In the World index and Polity IV. Comparative analysis shows the core factors which bring three different democratic concepts, used in the indices, to the integral unity. Finding correlation between factors of Ukrainian democracy, measured in the indices through a certain time period (2006-2018), helps getting integral look at the problem of non existent universal theoretic base for understanding democracy. The basic idea of the analysis, represented in this article, shows that different factors, used by indices in measuring democracy, do not evenly correlate in practice, though they represent holistic approach to the essence of democracy. Choosing specific theoretical approach of understanding democracy makes it hard for indices to fully measure real democracy. This analysis aims at searching correlation in different basic factors of democratic models, used by indices with different approaches. As the result of the analysis the article ranks a number of basic factors, used in three popular indices of democracy, according to the strength of correlation of these factors with other factors of the index they represent and with the final score of the index. Integral choice of the basic factors, which correlate with the change of Ukraine's democratic trends according to the three indices, covers several dimensions of democratic model. Ukrainian democratic trends in the specific time period (2006-2018), as the analysis shows, from integral point of view correlates the most with the changes in electoral process and pluralism, civil liberties and legal restrictions of the executive power. Political culture, political participation and individual rights show weak correlation with Ukrainian democratic trends within the period of time, chosen for the analysis.

Keywords: democracy, democratization, political regime, political system, Ukraine, indices, index of democracy

\section{Порівняльний аналіз ефективності демократії в Україні за індексами демократії The Economist Democracy Index, Freedom In the World та Polity IV}

\section{Катерина Федоришина, Київський національний торговельно-економічний університет}

Стаття представляє аналіз ефективності української демократії в межах трьох популярних індексів демократії - The Economist Democracy Index, Freedom In the World та Polity IV. Порівняльний аналіз демонструє основні фактори, що включають три різні демократичні концепції, які використовуються в індексах як єдине ціле. Визначення кореляції між факторами української демократії, що вимірювались за допомогою індексів за певний період часу (2006-2018рр.), дозволяє комплексно вивчити проблему відсутності універсальної теоретичної бази для розуміння конкретних особливостей демократії. Основна ідея аналізу, представленого в цій статті, визначає, що різні фактори індексів для вимірювання демократії на практиці не корелюють рівномірно, хоча і представляють собою цілісний підхід до сутності демократії. Фокус на конкретному теоретичному підході до розуміння демократії ускладнює повноцінне вимірювання реальної демократії за допомогою індексів. Даний аналіз спрямований на пошук кореляції в різних базових факторах демократичних моделей, що використовуються індексами з різними підходами. У результаті аналізу в статті визначається низка основних факторів, що використовуються в трьох популярних індексах демократії, залежно від сили кореляцій цих факторів з іншими факторами індексів, які вони представляють, і з фінальною оцінкою індексів. Інтегральний вибір 
основних факторів, які корелюють зі зміною демократичних тенденцій в Україні за трьома індексами, охоплює кілька вимірів демократичної моделі. Українські демократичні тенденції в конкретний період часу (2006-2018рр.), як свідчить аналіз, із інтегральної точки зору найсильніше корелюють зі змінами характеристик виборчого процесу та плюралізму, громадянських свобод та правових обмежень виконавчої влади. Політична культура, участь у політичному житті та індивідуальні права демонструють слабку кореляцію з українськими демократичними трендами протягом періоду часу, вибраного для аналізу.

Ключові слова: демократія, демократизачія, політичний режим, політична система, Україна, індекси, індекс демократії

\section{Сравнительный анализ эффективности демократии в Украине по индексам демократии The Economist Democracy Index, Freedom In the World и Polity IV}

\section{Екатерина Федоришина, Киевский национальный торгово-экономический университет}

Статья представляет собой анализ эффективности украинской демократии в рамках трех популярных индексов демократии - The Economist Democracy Index, Freedom In the World и Polity IV. Сравнительный анализ показывает основные факторы, которые сводят три различные демократические концепции, используемые в индексах, в единое целое. Определение корреляции между факторами украинской демократии, измеряемыми с помощью индексов за определенный период времени (2006-2018 гг.), позволяет комплексно взглянуть на проблему отсутствия универсальной теоретической базы для понимания отличительных особенностей демократии. Основная идея анализа, представленного в данной статье, заключается в том, что различные факторы, используемые индексами при измерении демократии, на практике не коррелируют равномерно, хотя и представляют собой целостный подход к сути демократии. Фокус на конкретном теоретическом подходе к пониманию демократии затрудняет полноценное измерение реальной демократии с помощью индексов. Данный анализ направлен на поиск корреляции в различных базовых факторах демократических моделей, используемых индексами с разными подходами. В результате анализа в статье ранжируется ряд основных факторов, используемых в трех популярных индексах демократии, в зависимости от силы корреляции этих факторов с другими факторами индекса, который они представляют, и с окончательной оценкой индекса. Интегральный выбор основных факторов, которые коррелируют с изменением демократических тенденций в Украине по трем индексам, охватывает несколько измерений демократической модели. Украинские демократические тенденции в конкретный период времени (2006-2018 гг.), как свидетельствует анализ, с интегральной точки зрения больше всего коррелируют с изменениями характеристик избирательного процесса и плюрализма, гражданскими свободами и правовыми ограничениями исполнительной власти. Политическая культура, участие в политической жизни и права личности показывают слабую корреляцию с украинскими демократическими тенденциями в течение периода времени, выбранного для анализа.

Ключевые слова: демократия, демократизаиия, политический режим, политическая система, Украина, индексы, индекс демократии

$\mathrm{P}$ olitical changes in Ukraine and specific transformations of the Ukrainian political regime show in practice what are the main characteristics of the phenomenon of the political regime. Accordingly, the analysis of transformation processes in Ukraine allows researchers to reveal the relationship between institutional and sociological approaches in

determining the foundations of the phenomenon of political regime. Thus, Yuriy Matsievsky considers the formation of a hybrid regime in Ukraine through transformation processes with a bias towards the institutional approach. For the researcher, the hybridization of the political regime in Ukraine, in fact, is a reflection of the slide to institutional imbalance, i.e. inefficient 
institutionality. Although for the researcher of the institutional approach there are certain limitations that do not allow to fully explain the transformational political processes in Ukraine (Matsievsky, 2016). But such approaches show the very essence of the problem, which basically explains the inability of political scientists to properly measure political regimes, democracy in particular.

The problem of unification of the concept of "political regime" is closely related to the complexity of the typology of political regimes. Different approaches to determining the essence of the phenomenon of political regime bring to the fore different characteristics of the phenomenon, respectively. If the attention of researchers is focused on the institutional dimension, avoiding attempts to add to them informal relations of the political system, the typology will be based on the very functioning of the system, leaving behind the political culture and political behavior. Conversely, the focus on social interaction, which bypasses the importance of the constitutional and legal dimension, leads to an imbalance in the characteristics that determine a particular political regime.

The problem of dividing political regimes into democratic and undemocratic is also complicated: what characteristics should be taken as a basis to define a political regime as democratic, which characteristics, among others, automatically classify a political regime as undemocratic.

But societies differ not only in the way they organize political life, but also in the specifics of their ties with political power in areas that have nothing to do with politics. Juan Linz writes about this, returning the discussion around the typology of political regimes to the source of the problem, which is rooted in determining the very specifics of the political regime. Thus, Linz notes that political systems themselves are diverse, and this poses a separate problem in the modern definition of "undemocracies." That is, in modern conditions it is difficult to clearly define what is not democracy. According to the researcher, a political system can be defined as democratic if it makes it possible to determine political advantages through freedom of assembly, information and communication, free competition between leaders, which at regular intervals nonviolently confirms leaders' claims to power (Linz, 2000).

Some other foreign researchers also point at the inability to unambiguously classify political regimes. From their point of view, the classification of regimes depends on the question to be answered by a study that uses one or another classification (Croissant et al., 2015).

However, the problem of the lack of a common theoretical approach to the definition of political regime, democracy, undemocratic political regime, as well as the problem of determining the types of political regimes leads to difficulties in measuring the efficiency of democracy. Thus, in political science, there are different approaches to measuring democracy using quantitative methods. The difference in approaches depends both on the chosen theoretical view of the essence of the political regime and democracy in particular, and on a more applied choice of the necessary characteristics of democracy that determine its efficiency.

Regarding the main approaches to measuring democracy, A. McCulloch points to the existence of two groups of tools for quantitative research of democratic political regimes (McCulloch, 2014). The first group uses an instrumental approach to create indices that measure individual characteristics of democratic regimes and, as a result, measure a political regime. The specificity of this approach shows that researchers choose a wide range of variables that describe the democratic regime. The second group, on the other hand, uses tools to identify the narrow set of characteristics inherent in democracy that form the basis of a democratic political regime, such as the electoral process and civil liberties. In other words, these two approaches directly reflect two approaches 
to the conceptual consideration of the peculiarities of a democratic political regime: the extended approach defines democracies through a large number of diverse factors, and the narrow approach seeks to reduce democracy to a minimum universal set of characteristics.

In general, if you choose between two approaches to quantitative analysis of the efficiency of democracy, minimalistic approach allows more accurate measurement through a limited number of variables, but it is less reliable in terms of a holistic concept of democracy, which in one way or another includes more characteristics than the electoral process and civil liberties.

In this regard, M. Coppege and J. Herring point to the impossibility of reaching a consensus on a common concept and methods of measuring political regimes. The problem points at the difficulty of comparing quantitative indicators by country and time interval. Without such comparisons, it is impossible to determine the progress or regression of the development of political regimes, draw conclusions and understand future trends, not to mention the patterns of transitions to democracy (Coppedge and Gerring, 2011).

In the discussion of measuring political regimes, in particular democracy, it is not possible to reach a universal concept of the mandatory characteristics of a particular type of political regime. Therefore, it is impossible to find a common method of measurement. The minimalist approach to describing the characteristics of democratic regimes has its drawbacks, but the extended approach, which includes too many variables, also has its drawbacks. The correlation of variables in both approaches remains a separate problem. Some variables in both the minimalist and the expanded approach to measuring democracies essentially conflict with the basic characteristics of democracy or reinforce other democratic variables (Coppedge and Gerring, 2011). In practice, this problem leads to the fact that the quantitative analysis of the efficiency of democracy in a particular country in a particular geopolitical environment should include several indices, different in approach. Comparing the measurement results on several indices makes it possible to obtain a more valid result.

By choosing indices with different rating scales, different basic concepts of democracy and, consequently, different sets of factors for analysis, one can get an expanded picture. This picture shows trends of on a wide range of factors, and the coincidence or divergence of indicators and their dynamics over time in several indices provides a tool for a deeper analysis of the development of political regimes.

Measuring democracy according to the indices The Economist Democracy Index, Freedom In the World and Polity IV

Among the most commonly used indices measuring political regimes in general and democracy in particular are the following: The Economist Democracy Index, Freedom In the World and Polity IV.

Each of the identified indices methodology is based on a separate concept of democracy, respectively, differing measurement factors, measurement scales and the final assessment of the efficiency of democracy.

The Economist Democracy Index measures political regimes on a scale of 0 to 10 (max), so countries fall into one of four groups that define a democratic or undemocratic regime full democracies (8 to 10 points), flawed democracies (6 up to 7.9 points), hybrid regimes (from 4 to 5.9) and authoritarian regimes (below 4 points).

The Economist Democracy Index uses five categories to measure the efficiency of the political regime: electoral process and pluralism, civil liberties, functioning of government, political participation, and political culture. At their core, these categories are linked into a single concept that defines the efficiency of a democratic political regime and, consequently, helps to measure undemocratic political regimes through indicators of the inefficiency of democratic factors. 
The Freedom In the World Index uses several different scales to measure the efficiency of political regimes. As a result, country measurements belong to one of three groups, according to the level of freedom within the country: free, partially free, not free. The efficiency of the political regime is assessed with an emphasis on civil rights and freedoms by two common groups of factors: political rights and civil liberties. Each group of factors is estimated from 1 ( $\max )$ to 7 (min). Both common groups of factors can be divided into subgroups: the electoral process, political pluralism and political participation, functioning of government, freedom of expression and belief, assotiational and organizational rights, rule of law, personal autonomy and individual rights.

Among the three most commonly used indices, the Polity IV project is the most concise, using a narrow concept of democracy, focusing on political competition and government rotation. Thus, Polity IV uses a concept that divides political regimes into three groups: democracies, autocracies, and anocracies (a mixed form with elements of democracies and autocracies, similar to a hybrid regime).

All three groups of political regimes are rated on a scale of 21 points, from -10 to +10 . Autocracies are in the group in terms of -10 to -6 , anocracies - in the range from -5 to +5 , democracies - from +6 to +10 .

The described indices use the method of expert evaluation, which introduces an element of subjectivity into the analysis process. However, the problem of validity in measuring democracy remains open to political science, as does the problem of the mismatch between measurement methods and the basic concepts of political regimes used by certain indices. Nevertheless, comparing the results of the analysis of the efficiency of democracy in Ukraine according to the three indices, it is possible to get a multidimensional picture that allows to assess the trends of democratic development in the country.

The efficiency of Ukraine's democracy in 2006-2018 according to The Economist Democracy Index

To analyze the efficiency of Ukraine's democracy, it is possible to use the three indices described above. However, when choosing the time period for analysis, we must rely on the specifics of the indices themselves. For example, The Economist Democracy Index began presenting the results of measuring the efficiency of democracies only in 2006, and Polity IV ends the project data with 2018, developing new methods and new approaches for future analysis. Therefore, the common time interval for the selected indices should be the period from 2006 to 2018 .

Within the framework of The Economist Democracy Index, the indicators of the efficiency of democracy in Ukraine for 2006-2018 are as follows (Tab. 1):

Table 1

Source of the data - The Economist Democracy Index White Papers

\begin{tabular}{|l|r|r|r|r|r|r|r|r|r|r|r|}
\hline $\begin{array}{l}\text { The } \\
\text { Economist } \\
\text { Democracy } \\
\text { Index } \\
\mathbf{2 0 0 6 - 2 0 1 8}\end{array}$ & $\mathbf{2 0 0 6}$ & $\mathbf{2 0 0 8}$ & $\mathbf{2 0 1 0}$ & $\mathbf{2 0 1 1}$ & $\mathbf{2 0 1 2}$ & $\mathbf{2 0 1 3}$ & $\mathbf{2 0 1 4}$ & $\mathbf{2 0 1 5}$ & $\mathbf{2 0 1 6}$ & $\mathbf{2 0 1 7}$ & $\mathbf{2 0 1 8}$ \\
\hline Ukraine & 6.94 & 6.94 & 6.3 & 5.94 & 5.91 & 5.84 & 5.42 & 5.7 & 5.7 & 5.69 & 5.69 \\
\hline
\end{tabular}

According to the index methodology, until 2011 Ukraine was part of the group of flawed democracies; from 2011 to 2018 Ukraine belonged in the group of hybrid regimes.

In general, from 2006 to 2018, Ukraine is experiencing several radical changes in the 
efficiency of democracy. Thus, in 2014 the country received the lowest (for the analyzed time period) indicator of 5.42 points, in 2006 and 2008 the indicators were the highest -6.94 points. From 2011 to 2014, we can see a gradual decline in the efficiency of democracy, and from 2014 to 2018 the indicators are stable, although they do not show a return to pre-crisis conditions (until 2011).

Thus, the dynamics of changes in the efficiency of democracy in Ukraine as a whole for a certain period of time according to The Economist Democracy Index has the following main points of change: year 2010, 2014 and 2015. The three time points correspond to key changes in the country's political system. For a detailed analysis of changes in the efficiency of democracy in Ukraine in the specified time period for the selected index, let's look at the distribution of scores on individual factors of the index (Tab.2):

Source of the data - The Economist Democracy Index White Papers

Table 2

\begin{tabular}{|l|l|l|l|l|l|}
\hline $\begin{array}{l}\text { Ukraine's } \\
\text { democracy } \\
\text { represented } \\
\text { through the } \\
\text { separate } \\
\text { factors of } \\
\text { The } \\
\text { Economist } \\
\text { Democracy } \\
\text { Index }\end{array}$ & $\begin{array}{l}\text { Electoral } \\
\text { process } \\
\text { and } \\
\text { pluralism }\end{array}$ & $\begin{array}{l}\text { Government } \\
\text { fumctioning }\end{array}$ & $\begin{array}{l}\text { Political } \\
\text { participation }\end{array}$ & $\begin{array}{l}\text { Political } \\
\text { culture }\end{array}$ & Civil \\
\hline 2006 & 9.58 & 5.71 & 5.56 & 5.63 & liberties \\
\hline 2008 & 9.58 & 5.36 & 5.56 & 6.25 & 7.94 \\
\hline 2010 & 9.17 & 5 & 5 & 4.38 & 7.94 \\
\hline 2011 & 8.33 & 4.64 & 5 & 4.38 & 7.35 \\
\hline 2012 & 7.92 & 4.64 & 5.56 & 4.38 & 7.06 \\
\hline 2013 & 7.92 & 4.29 & 5.56 & 4.38 & 7.06 \\
\hline 2014 & 5.83 & 3.93 & 5.56 & 5 & 6.76 \\
\hline 2015 & 5.83 & 3.93 & 6.67 & 5 & 7.06 \\
\hline 2016 & 5.83 & 3.93 & 6.67 & 5 & 7.06 \\
\hline 2017 & 6.17 & 3.21 & 6.67 & 6.25 & 6.18 \\
\hline 2018 & 6.17 & 3.21 & 6.67 & 6.25 & 6.18 \\
\hline
\end{tabular}

The general annual score of the index shows the weakening of the efficiency of democracy in Ukraine from 2006 to 2014, from 2015 to 2018 there is a gradual increase in indicators without returning to pre-crisis levels.

According to some indicators, these changes can be seen as follows. Indicators of "electoral process and pluralism" are the highest in 2006 and 2008 and the lowest from 2014 to 2016. Since 2010, these indicators have been steadily declining, which is in line with the general trend in the country. Thus, it can be concluded that changes in the efficiency of the electoral process and political pluralism are associated with changes in the efficiency of democracy in the country in general.

The factor "functioning of the government" demonstrates similar changes - the highest score from the described time period Ukraine attains in 2006 and observes a steady decline in the indicator, as well as a sharp decline since 2014. This factor also shows a decline after 2010, which is in line with the general trend in the country. Thus, it can be concluded that changes in the efficiency of government are also related to changes in the efficiency of democracy in Ukraine in the specified period of time. 
The civil liberties factor is more stable, but in general is also gradually declining, including a sharp jump in 2014. Thus, changes in civil liberties are partly related to changes in the general trend of democracy efficiency in Ukraine in 2006-2018.

The factors "political participation" and "political culture" have a different situation with indicators, which does not correspond to the general trend of changes of Ukrainian democracy in 2006-2018.

The indicator of "political participation" is mostly stable, we can see a slight decrease in 2010, since 2015 we see its improvement and a stable trend. The indicator of "political culture" in general does not correspond to changes in the general trend of the country, shows the highest score in 2008, a sharp decline - in 2010 and a gradual improvement - since 2014. Thus, changes in political participation and political culture are more autonomous, they are weakly related to general changes in Ukraine's democracy performance over time.

The method of correlation analysis confirms the uneven correlation of certain factors with changes in the efficiency of democracy in Ukraine for 2006-2018. The correlation of some factors of the index with the general index

Source of the data-personal calculation

Table 3

\begin{tabular}{|c|c|c|c|c|}
\hline $\begin{array}{l}\text { Electoral } \\
\text { process and } \\
\text { pluralism } \\
\text { factor of The } \\
\text { Economist } \\
\text { Democracy } \\
\text { Index } \\
\text { correlation } \\
\text { with the } \\
\text { general index } \\
\text { for Ukraine }\end{array}$ & $\begin{array}{l}\text { Government } \\
\text { functioning } \\
\text { factor of The } \\
\text { Economist } \\
\text { Democracy } \\
\text { Index } \\
\text { correlation } \\
\text { with the } \\
\text { general index } \\
\text { for Ukraine }\end{array}$ & $\begin{array}{l}\text { Political } \\
\text { participation } \\
\text { factor of The } \\
\text { Economist } \\
\text { Democracy } \\
\text { Index } \\
\text { correlation } \\
\text { with the } \\
\text { general index } \\
\text { for Ukraine }\end{array}$ & $\begin{array}{l}\text { Political culture } \\
\text { factor of The } \\
\text { Economist } \\
\text { Democracy } \\
\text { Index } \\
\text { correlation with } \\
\text { the general } \\
\text { index for } \\
\text { Ukraine }\end{array}$ & $\begin{array}{l}\text { Civil } \\
\text { freedoms } \\
\text { factor of The } \\
\text { Economist } \\
\text { Democracy } \\
\text { Index } \\
\text { correlation } \\
\text { with the } \\
\text { general } \\
\text { index for } \\
\text { Ukraine }\end{array}$ \\
\hline 0.885308 & 0.867005 & -0.43855 & 0.243696 & 0.842271 \\
\hline
\end{tabular}

for Ukraine in 2006-2018 is as follows (Tab 3):

Thus, the factors "electoral process and pluralism", "functioning of government" and "civil liberties" are strongly related to changes of the efficiency of democracy in Ukraine in 2006-2018, the factor "political participation" has a weak correlation with changes of the efficiency of democracy in the country, and the factor of "political culture" shows a very weak correlation as well.

Thus, according to The Economist Democracy Index in the period 2006-2018, the weakening or strengthening of democracy in
Ukraine is strongly associated with institutional changes - the efficiency of the electoral process, the specifics of political pluralism, the functioning of government and civil liberties. However, the strengthening or weakening of political participation and political culture in the country has very little to do with the strengthening and weakening of democratic processes in Ukraine? According to the index measurement.

The efficiency of Ukraine's democracy in 2006-2018 according to the Freedom In the World index. 
The Freedom In the World Index uses a general scale for measuring the efficiency of democracy from 1 (max) to $7(\mathrm{~min})$ points and a more detailed scale for measuring individual factors by two groups. Indicator 1 corresponds to a liberal democracy that is completely free (1 to 2.5); a score of 3 to 5 corresponds to partially free countries, which may also include electoral but not liberal democracies; the figure from 5.5 to 7 does not correspond to free countries or non-democracies. Indicator 1 corresponds quantitatively to the total score of 100, which in turn consists of assessments of 2 groups of factors - political rights ( 3 factors, estimated at 40 points maximum) and civil liberties (4 factors, estimated at 60 points maximum).

Accordingly, the analysis of the index provides an opportunity to look at the general assessment of the state of democracy in the country, and individual, more detailed variables that form the basis of the concept of liberal democracy.

The following table shows the dynamics of Ukraine's democracy efficiency indicators from 2006 to 2018 according to the Freedom In the World index (Tab 4).

Table 4

Source of the data - The Economist Democracy Index White Papers

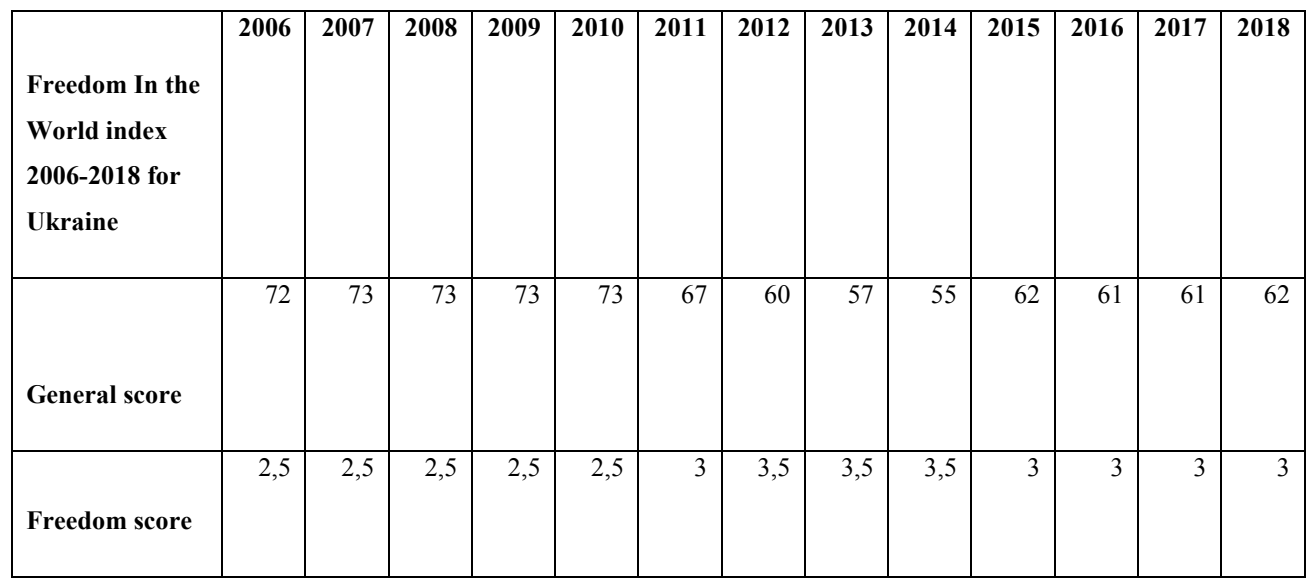

The Freedom In the World index uses the concept of liberal democracy as the theoretical reference to analyze political regimes, so the category of freedom corresponds to the category of "full democracy" or "free country". Thus, the indicator that measures the degree of freedom according to this index is an indicator that measures the efficiency of democracy as such.

The efficiency of Ukraine's democracy from 2006 to 2018 in the indicators of the Freedom In the World index has several turning points. 2014 within the index corresponds to the lowest freedom indicator for the country for the specified period (55 points), from 2007 to 2010 the index shows a stable indicator, the highest of the entire analyzed period. Since 2011, there is a sharp decline (from 73 to 67 points), Ukraine becomes part of a group of partially free states, out of the category of liberal, and therefore completely free democracies. After 2014, Ukraine shows improvement in the efficiency of democracy, but does not return to the category of liberal, completely free democracies.

The following table shows the indicators for Ukraine on the selected factors of the index (Tab. 5):

Comparing the dynamics of changes in individual indicators of the index and the overall score for Ukraine in a certain period of time, there are differences that indicate the heterogeneous strength of various factors with the trend of changing the efficiency of democracy.

Indicators of freedom have been declining in both groups of factors since 2011, the group of factors "civil liberties" is losing the level of indicators of freedom significantly (from 45 to 40 points), and the group of factors "political rights" - 
Source of the data - the Freedom In the World Index White Papers

\begin{tabular}{|c|c|c|c|c|c|c|c|c|c|}
\hline $\begin{array}{c}\text { Factors of } \\
\text { the } \\
\text { Freedom } \\
\text { In the } \\
\text { World } \\
\text { index for } \\
\text { Ukraine } \\
\text { 2006-2018 }\end{array}$ & $\begin{array}{c}\text { Political } \\
\text { rights }\end{array}$ & $\begin{array}{c}\text { Civil } \\
\text { liberties }\end{array}$ & $\begin{array}{l}\text { Political } \\
\text { rights - } \\
\text { electoral } \\
\text { process }\end{array}$ & $\begin{array}{c}\text { Political } \\
\text { rights - } \\
\text { pluralism } \\
\text { and } \\
\text { participati } \\
\text { on }\end{array}$ & $\begin{array}{c}\text { Political } \\
\text { rights - } \\
\text { governme } \\
\text { nt } \\
\text { functionin } \\
\text { g }\end{array}$ & $\begin{array}{l}\text { Civil } \\
\text { liberties - } \\
\text { freedom of } \\
\text { expression } \\
\text { and belief }\end{array}$ & $\begin{array}{c}\text { Civil } \\
\text { liberties - } \\
\text { associatio } \\
\text { nal and } \\
\text { organisati } \\
\text { onal rights }\end{array}$ & $\begin{array}{c}\text { Civil } \\
\text { liberties - } \\
\text { rule of law }\end{array}$ & $\begin{array}{c}\text { Civil } \\
\text { liberties - } \\
\text { personal } \\
\text { autonomy } \\
\text { and } \\
\text { individual } \\
\text { rights }\end{array}$ \\
\hline 2006 & 27 & 45 & 8 & 12 & 7 & 13 & 10 & 11 & 11 \\
\hline 2007 & 28 & 45 & 9 & 13 & 6 & 13 & 10 & 11 & 11 \\
\hline 2008 & 29 & 44 & 10 & 13 & 6 & 13 & 10 & 10 & 11 \\
\hline 2009 & 28 & 45 & 10 & 13 & 5 & 13 & 11 & 10 & 11 \\
\hline 2010 & 28 & 45 & 10 & 13 & 5 & 13 & 11 & 10 & 11 \\
\hline 2011 & 27 & 40 & 9 & 13 & 5 & 11 & 9 & 9 & 11 \\
\hline 2012 & 23 & 37 & 9 & 10 & 4 & 10 & 8 & 8 & 11 \\
\hline 2013 & 21 & 36 & 8 & 9 & 4 & 10 & 8 & 7 & 11 \\
\hline 2014 & 20 & 35 & 8 & 8 & 4 & 9 & 8 & 7 & 11 \\
\hline 2015 & 25 & 37 & 9 & 10 & 6 & 11 & 9 & 6 & 11 \\
\hline 2016 & 25 & 36 & 9 & 10 & 6 & 11 & 9 & 6 & 10 \\
\hline 2017 & 25 & 36 & 9 & 10 & 6 & 11 & 9 & 6 & 10 \\
\hline 2018 & 26 & 36 & 9 & 11 & 6 & 11 & 9 & 6 & 10 \\
\hline
\end{tabular}

insignificant(from 28 to 27 points). Considering the individual factors and their number in the selected time period, there is a significant decrease in the indicators of "freedom of expression and belief" of the group "civil liberties" and "assotiational and organizational rights" of the group "civil liberties". The factors "pluralism and participation" of the group "political rights", "functioning of the government" of the group "political rights" and "personal autonomy and individual rights" of the group "civil liberties" remain stable. Thus, the decline in Ukraine's democracy performance in 2011, as a result of which Ukraine left the group of liberal or completely free democracies, is largely due to the deterioration of freedom of expression and the situation with freedom of assembly.
Correlation analysis makes it possible to calculate the strength of the links of both groups of factors with the general indicator of the efficiency of democracy in Ukraine in the specified period (Tab.6):

Despite the difference between the fluctuations of individual factors of the represented groups in comparison with the general trend of changing the efficiency of democracy in Ukraine in 2006-2018, both groups of factors have strong connection with the trend. But to check the balance of the factors selected for analysis, it is worth looking at the correlation of factors with each other, how their changes and fluctuation trends are related. It is also necessary to determine the links between individual factors and the overall performance 
Source of the data-personal calculation

\begin{tabular}{|l|l|}
\hline $\begin{array}{l}\text { Correlation of the factors of } \\
\text { «political rights» group and the } \\
\text { general score for Ukraine in the }\end{array}$ \\
Freedom In the World index 2006- \\
$\mathbf{2 0 1 8}$ & -0.93067 \\
\hline $\begin{array}{l}\text { Correlation of the factors of «civil } \\
\text { liberties» group and the general } \\
\text { score for Ukraine in the Freedom }\end{array}$ \\
In the World index 2006-2018 & -0.88172 \\
\hline
\end{tabular}

Source of the data-personal calculation

\begin{tabular}{|c|c|c|c|c|c|c|c|}
\hline $\begin{array}{l}\text { Correlation of } \\
\text { the separate } \\
\text { factors of the } \\
\text { Freedom in The } \\
\text { World index for } \\
\text { Ukraine 2006- } \\
2018\end{array}$ & $\begin{array}{c}\text { Political } \\
\text { rights - } \\
\text { electoral } \\
\text { process }\end{array}$ & $\begin{array}{c}\text { Political } \\
\text { rights - } \\
\text { pluralism and } \\
\text { participation }\end{array}$ & $\begin{array}{c}\text { Political } \\
\text { rights - } \\
\text { government } \\
\text { functioning }\end{array}$ & $\begin{array}{c}\text { Civil } \\
\text { liberties - } \\
\text { freedom of } \\
\text { expression } \\
\text { and belief }\end{array}$ & $\begin{array}{c}\text { Civil } \\
\text { liberties - } \\
\text { associational } \\
\text { and } \\
\text { organisation } \\
\text { al rights }\end{array}$ & $\begin{array}{c}\text { Civil } \\
\text { liberties - } \\
\text { rule of law }\end{array}$ & $\begin{array}{l}\text { General } \\
\text { score }\end{array}$ \\
\hline $\begin{array}{l}\text { Political rights - } \\
\text { electoral process }\end{array}$ & 0,664964 & 0,122663 & 0,592912518 & $\begin{array}{l}0,68547758 \\
4\end{array}$ & 0,293688021 & 0 & 0,611069 \\
\hline $\begin{array}{c}\text { Political rights - } \\
\text { pluralism and } \\
\text { participation }\end{array}$ & & 0,402814 & 0,881248086 & 0,83800347 & 0,78597481 & 0,263932 & 0,950029 \\
\hline $\begin{array}{c}\text { Political rights - } \\
\text { government } \\
\text { functioning }\end{array}$ & & & 0,604207105 & $\begin{array}{l}0,45922239 \\
4\end{array}$ & 0,166268101 & $-0,36515$ & 0,481364 \\
\hline $\begin{array}{c}\text { Civil liberties - } \\
\text { freedom of } \\
\text { expression and } \\
\text { belief }\end{array}$ & & & & $\begin{array}{l}0,93791132 \\
4\end{array}$ & 0,764646914 & 0,189107 & 0,968512 \\
\hline $\begin{array}{l}\text { Civil liberties - } \\
\text { associational and } \\
\text { organisational } \\
\text { rights }\end{array}$ & & & & & 0,687573466 & 0,170046 & 0,918761 \\
\hline $\begin{array}{c}\text { Civil liberties - } \\
\text { rule of law }\end{array}$ & & & & & & 0,633839 & 0,861899 \\
\hline $\begin{array}{l}\text { Civil liberties - } \\
\text { personal } \\
\text { autonomy and } \\
\text { individual rights }\end{array}$ & & & & & & & 0,335658 \\
\hline
\end{tabular}

of Ukraine's democracy over a period of time (Tab. 7):

First of all, we see that in both groups of factors there are factors whose correlation shows weak connection with the overall score of freedom (efficiency of democracy). In the case of a weak link, we can say that the calculation of this factor does not affect the final verdict on the situation with democracy in the country, or the effect is weak. Such are the factors: "the functioning of the government" and the factor "personal autonomy and individual rights". Even if the "functioning of the government" factor shows episodic fluctuations that sharply coincide 
with the fluctuations of the overall rating and determines the change in the trend (as in the case of the change from 2014 to 2015), in the general period this factor is weakly consistent with the whole trend. Consifdering the fluctuations of the indicators of the factor "personal autonomy and individual rights", even weak fluctuations in accordance with the general trend of the country are absent.

The largest number of factors with the highest correlation coefficient with the overall rating of the index belongs to the group of "civil liberties". And the highest correlation coefficient in the group of "political rights" refers to a factor that combines not only a purely functional dimension (such as the electoral process or the functioning of government), but includes a focus on the individual dimention. As a result, we see that the focus of the chosen concept of democracy, even if it includes additional basic factors, mainly determines the final result of the assessment of freedom (efficiency of democracy).

As in the case of The Economist Democracy Index, which included the measurement of culture and political behavior in the list of factors, the focus on functionality is specifically highlighted in factors related to the overall outcome of democracy performance. In the situation with Freedom In the World, the focus on the liberal concept through the prism of individual rights and freedoms, even taking into account the institutional and functional approach, determines the asymmetric correlation of various factors. It also brings us back to the already mentioned problem of choosing the most complete concept, which would include a sufficient number of factors to assess the political regime from all the necessary dimensions, provided the factors are symmetrical on the result and there is no conflict between factors.

The results of the correlation analysis in the Freedom In the World index for Ukraine indicate that the factors with a weak correlation with an overall score are those factors that have the lowest correlation coefficients with other factors. Thus, the "functioning of the government" of the group "political rights" and "personal autonomy and individual rights" of the group "civil liberties" almost do not correlate with other factors. Interestingly, there is a medium correlation between the "functioning of government" factor and the "freedom of expression and belief" factor, as well as between the "personal autonomy and individual rights" factor and the "rule of law". These selected factors do not correlate with other factors. Thus, we can conclude that "the functioning of government" and "personal autonomy and individual rights", firstly, are not related, secondly, have almost no effect on the overall rating, and thirdly, represent their own dynamics, which does not coincide with the chosen concept of assessing the freedom (efficiency of democracy) within this index for Ukraine in the chosen time period.

In general, the trend of changing the efficiency of Ukraine's democracy according to the Freedom In the World index corresponds to the trend of changing the efficiency of Ukraine's democracy according to The Economist Democracy Index in a certain period of time.

The efficiency of Ukraine's democracy in 2006-2017 according to the Polity IV index

Unlike The Economist Democracy Index and Freedom In the World, the Polity IV project represents the most minimalist approach to measuring political regimes.

To analyze the peculiarities of political regimes, the Polity IV project identifies factors that determine the specifics of political competition, rotation and recruting for key government positions.

The following indicators characterize the specifics of the political regime of Ukraine in the selected period of time according to the Polity IV index (Tab. 8):

Looking at the trends of democratic changes in Ukraine for the selected period of time in the Polity IV index, we see a more stable picture, showing significant changes (downfalls) in 2010 and 2014 and generally consistent with trends described by two other indices - The 
Source of the data-personal calculation

Table 8

\begin{tabular}{|c|c|c|c|c|c|c|}
\hline $\begin{array}{l}\text { Polity IV } \\
\text { Index for } \\
\text { Ukraine } \\
\text { 2006-2017 }\end{array}$ & $\begin{array}{l}\text { Factor } \\
\text { EXREC }\end{array}$ & $\begin{array}{l}\text { Factor } \\
\text { EXCONST }\end{array}$ & $\begin{array}{l}\text { Factor } \\
\text { POLC } \\
\text { OMP }\end{array}$ & $\begin{array}{l}\text { Index } \\
\text { DEM }\end{array}$ & $\begin{array}{l}\text { Index } \\
\text { AUTOC }\end{array}$ & $\begin{array}{l}\text { General } \\
\text { score } \\
\text { POLITY2 }\end{array}$ \\
\hline 2006 & 8 & 6 & 7 & 7 & 0 & 7 \\
\hline 2007 & 8 & 6 & 7 & 7 & 0 & 7 \\
\hline 2008 & 8 & 6 & 7 & 7 & 0 & 7 \\
\hline 2009 & 8 & 6 & 7 & 7 & 0 & 7 \\
\hline 2010 & 8 & 5 & 7 & 6 & 0 & 6 \\
\hline 2011 & 8 & 5 & 7 & 6 & 0 & 6 \\
\hline 2012 & 8 & 5 & 7 & 6 & 0 & 6 \\
\hline 2013 & 8 & 5 & 7 & 6 & 0 & 6 \\
\hline 2014 & 7 & 5 & 6 & 5 & 1 & 4 \\
\hline 2015 & 7 & 5 & 6 & 5 & 1 & 4 \\
\hline 2016 & 7 & 5 & 6 & 5 & 1 & 4 \\
\hline 2017 & 7 & 5 & 6 & 5 & 1 & 4 \\
\hline
\end{tabular}

Economist Democracy Index and Freedom In the World.

In the Polity IV index for Ukraine, 2010 is determined by the decrease of the factor "institutional constraints of the executive power". For comparison, the Freedom In the World index for this period of time (2011) has a sharp deterioration in the performance of the group of "civil liberties" in Ukraine, which led to the country's exit from the group of "free countries" and the transition to the group of "partially free". The deterioration of civil liberties during this period according to the Freedom In the World index also implies a decrease in the indicators of the factor "freedom of expression and belief" and "assotiational and organizational rights".

Considering the factor "institutional constraints of the executive branch" (exconst) in the Polity IV index, there are the instruments of limiting the power of the key representatives of the executive branch, equality or inequality of branches of government and their subordination included in this broader factor. The indicators of this factor of the Polity IV index correspond in practice to the indicators of the factors of the index The Economist Democracy Index. The Economist Democracy Index 2010-2011 in Ukraine is also marked by a sharp decline in the indicators of the factors "electoral process and pluralism" and "functioning of government".

Thus, considering the minimalist concept of measuring the efficiency of democracy in the Polity IV project in Ukraine for 2006-2017, we can see the following picture of the correlation of factors with the overall rating of the index (Tab.9): 


\section{Source of the data-personal calculation}

\begin{tabular}{|l|r|}
\hline $\begin{array}{l}\text { Factors of the } \\
\text { Polity IV index } \\
\text { for Ukraine in } \\
\mathbf{2 0 0 6 - 2 0 1 7}\end{array}$ & $\begin{array}{r}\text { Correlation of the index } \\
\text { factor with the general } \\
\text { score of the Polity IV for } \\
\text { Ukraine 2006-2017 }\end{array}$ \\
\hline Factors exrec & 0,944911 \\
\hline Factors exconst & 0,755929 \\
\hline Factors polcomp & 0,944911 \\
\hline
\end{tabular}

All three generalized factors show strong and very strong correlation with the overall performance of democracy in Ukraine in the Polity IV index for 2006-2017.
It is necessary to also calculate the correlations of generalized factors of the Polity IV index for Ukraine for 2006-2017 among themselves (Tab.10):

Table 10

Source of the data-personal calculation

\begin{tabular}{|c|c|c|}
\hline $\begin{array}{l}\text { Correlation within the } \\
\text { index factor of the } \\
\text { Polity IV for Ukraine } \\
2006-2017\end{array}$ & $\begin{array}{l}\text { Factors } \\
\text { exconst }\end{array}$ & $\begin{array}{l}\text { Factors } \\
\text { polcomp }\end{array}$ \\
\hline Factors exrec & 0,5 & 1 \\
\hline Factors exconst & & 0,5 \\
\hline
\end{tabular}

As a result of the analysis presented above, it should be emphasized that even a minimalist approach to determining the nature of political regimes and their specific types does not completely coincide with the practical results of the analysis of the efficiency of democracy.

\section{Conclusions}

In general, both indices - The Economist Democracy Index and Freedom In the World show a coincidence of the trends that determine the change in the efficiency of Ukraine's democracy in certain time periods for 20062018 .

Analyzing the efficiency of Ukraine's democracy according to the Polity IV index, which represents the theoretical pole of the minimalist approach to measuring democracy, the author of the study identifies a similar picture shown by The Economist Democracy Index and Freedom In the World, however, with some features.
Based on the indicators of the Polity IV index for Ukraine for 2006-2017, the factor "institutional constraints of the executive power" (exconst) shows weaker correlation coefficient with two other factors. The difference is significant, because the factors "rotation of executive power" (exrec) and "political competition" (polcomp) show a complete correlation, their correlation coefficient $=1$. In terms of time periods critical for the efficiency of Ukraine's democracy in 2006-2017, the Polity IV index shows a relative coincidence with The Economist Democracy Index and Freedom In the World.

Using the abovementioned calculations and analysis it is possible to rank the factors according to the degree of influence on democratic trend in Ukraine for 2006-2018 according to all analyzed indices together. When comparing factors, it is necessary to pay attention not only at the comparison of the 
actual factors, it is more important to compare the dimensions of the efficiency of democracy, which are represented by a certain set of factors.

Comparing the rankings of factors by the represented indices demonstrates the conflicts and universal points in the theoretical basis used by the indices to measure political regimes, in particular democracies (Tab.11):

Table 11

Source of the data-personal calculation

\begin{tabular}{|c|c|c|c|}
\hline The factor rank & $\begin{array}{llr}\text { Factors } & \text { of } & \text { The } \\
\text { economist } & \text { Democracy } \\
\text { Index } & \text { (ranked } \\
\text { according } & \text { to } \quad \text { the } \\
\text { correlation with other } & \text { factors and the general } \\
\text { score of the index for } \\
\text { Ukraine) }\end{array}$ & $\begin{array}{l}\text { Factors of the } \\
\text { Freedom In the } \\
\text { World (ranked } \\
\text { according to the } \\
\text { correlation with } \\
\text { other factors and } \\
\text { the general score of } \\
\text { the index for } \\
\text { Ukraine) }\end{array}$ & $\begin{array}{l}\text { Factors of the } \\
\text { Polity IV (ranked } \\
\text { according to the } \\
\text { correlation with } \\
\text { other factors and } \\
\text { the general score } \\
\text { of the index for } \\
\text { Ukraine) }\end{array}$ \\
\hline 1 & $\begin{array}{l}\text { Electoral process and } \\
\text { pluralism }\end{array}$ & $\begin{array}{lr}\text { Freedom } & \text { of } \\
\text { expression and } \\
\text { believe }\end{array}$ & $\begin{array}{l}\text { Executive } \\
\text { rotation }\end{array}$ \\
\hline 2 & $\begin{array}{l}\text { Functioning of } \\
\text { government }\end{array}$ & $\begin{array}{l}\text { Pluralism and } \\
\text { participation }\end{array}$ & $\begin{array}{l}\text { Political } \\
\text { competition }\end{array}$ \\
\hline 3 & Civil liberties & $\begin{array}{l}\text { Associational } \\
\text { and } \\
\text { organizational } \\
\text { rights }\end{array}$ & $\begin{array}{l}\text { Constraints of } \\
\text { the executive } \\
\text { power }\end{array}$ \\
\hline 4 & Political participation & Rule of law & \\
\hline 5 & Political culture & Electoral process & \\
\hline 6 & & $\begin{array}{l}\text { Functioning of } \\
\text { government }\end{array}$ & \\
\hline 7 & & $\begin{array}{l}\text { Personal } \\
\text { autonomy and } \\
\text { individual rights }\end{array}$ & \\
\hline
\end{tabular}

Reducing all three groups of factors of the considered indices for Ukraine in 2006-2018 to one ranking, having allocated coincidences or the positions closest on a rank, there is the following list of factors which are equally strongly connected with measurement of efficiency of democracy of the country in the chosen period of time:

1. Electoral process and pluralism.
2. Civil liberties, including assotiational and organizational rights, freedom of expression and belief, and political participation.

3. Institutional and legal restrictions on the executive power.

This result shows the abovementioned factors recommended as the core factors for an integral approach to measuring democracy in case of Ukraine and its democratic efficiency. 


\section{REFERENCES}

Burnell, P. (2010). Promoting Democracy and Promoting Autocracy: Towards a Comparative Evaluation. Journal of Politics and Law, 3 (2), 3-14.

Cavatorta, F. (2001). Geopolitical Challenges to the Success of Democracy in North Africa: Algeria, Tunisia and Morocco. Democratization, 8(4), 175-194.

Coppedge, M., \& Gerring, J. (2011). Conceptualizing and Measuring Democracy: A New Approach. Perspectives on Politics, 9(2), 247-267.

Croissant, A., Kailitz, S., Koellner, P., \& Wurster, S. (2015). Comparing autocracies in the early Twenty-first Century: Volume 1: Unpacking Autocracies - Explaining Similarity and Difference. Routledge, New York, USA.

D’Anieri, Paul. (2015). Democracy and Geopolitics: Understanding Ukraine's Threat to Russia. Ukraine and Russia. People, Politics, Propaganda and Perspectives. (pp. 221-228). E-International Relations Publishing, Bristol.

Fisun, O. A. (2008). Politychnyi rezhym Ukrainy u porivnialnii perspektyvi [The political regime of Ukraine in a comparative perspective]. Stratehichni priorytety - Strategic Priorities, 1(6), 5-12 [in Ukrainian].

Freedom In the World, Final Report. (2016). Retrieved from https://freedomhouse.org/report/freedom-world/ freedom-world-2016.

Freedom In the World, Final Report. (2017). Retrieved from https://freedomhouse.org/sites/default/files/FH FIW 2017 Report Final.pdf

Linz, Juan J. (2000). Totalitarian and Authoritarian Regimes. Lynne Rienner Publishers Inc, London, UK.

Matsiievskyi, Yu. (2016). U pasttsi hibrydnosti: zyhzahy transformatsii politychnoho rezhymu v Ukraini (19912014) [Trapped in Hybridity: Zigzags of Political Regime Transformations in Ukraine (1991-2014)]. Extended abstract of doctor's thesis. Kyiv.

McCulloch, A. (2014). How To Measure Democracy. Significance Magazine. Retrieved from https://www. significancemagazine.com/science/392-how-to-measure-democracy.

The Economist Democracy Index. (2007). Retrieved from https://pages.eiu.com/rs/753-RIQ-438/images/ Democracy_Index 2007.pdf.

The Economist Democracy Index. (2010). Retrieved from https://pages.eiu.com/rs/753-RIQ-438/images/ Democracy_Index_2010.pdf.

The Economist Democracy Index. (2016). Retrieved from http://www.eiu.com/Handlers/WhitepaperHandler. ashx?fi=Democracy-Index-2016.pdf\&mode=wp\&campaignid=DemocracyIndex2016.

The Polity IV Index Reports. (2006-2017). Retrieved from http://www.systemicpeace.org/inscr/.

\section{Федоришина Катерина}

Аспірант

Київський національний торговельно-економічний університет

Email: ekafedorishina@gmail.com

\section{Fedoryshyna Kateryna}

Ph.D. Student

Kyiv National University of Trade and Economics

Цитування: Федоришина, К. (2020). Порівняльний аналіз ефективності демократії в Україні за індексами демократіï The Economist Democracy Index, Freedom In the World та Polity IV. Науковотеоретич-ний альманах «Грані», 23 (8), 78-92. doi: 10.15421/172077

Citation: Fedoryshyna, K. (2020). Comparative analysis of efficiency of democracy in Ukraine according to the indices of democracy The Economist Democracy Index, Freedom In the World and Polity IV. Scientific and theoretical almanac «Grani», 23 (8), 78-92. doi: 10.15421/172077

Стаття надійшла / Article arrived: 16.09.2020

Схвалено до друку / Accepted: 14.10.2020 